\title{
GEOPHYSICS
}

\section{GEOPHYSICAL STUDIES OF BASIN STRUCTURES ALONG THE EASTERN FRONT OF THE SIERRA NEVADA, CALIFORNIA $\dagger$}

\author{
J. H. HEALY* AND FRANK PRESS +
}

A seismic and gravity survey along the eastern front of the Sierra Nevada, California, between southern Owens Valley and the Garlock fault, outlines a series of basins with maximum depths ranging from 5,000 to 9,000 ft. These basins follow the front of the Sierra Nevada in a continuous chain with one interruption of about 10 miles near Little Lake. The gravity anomalies indicate that the basins are bounded by a series of high-angle faults rather than a single large fault. The seismic velocities in the basin deposits appear to correlate with the stratigraphy of the section exposed in the El Paso Mountains. A comparison of Bouguer anomalies with seismic depths indicates a density contrast of $0.35 \mathrm{~g} / \mathrm{cc}$ in basins less than $3,000 \mathrm{ft}$ deep, and an average but widely varying density contrast of $0.25 \mathrm{~g} / \mathrm{cc}$ in basins 4,000 to $8,000 \mathrm{ft}$ deep. A digital-computer program for automatic computation of basin depths from gravity anomalies was evaluated and found to be useful in this type of analysis.

Changes in the depth to the Mohorovicić discontinuity cannot produce regional gradients as large as the regional gradients observed in the area of the survey. Fither structure on an intermediate crustal boundary or lateral changes in crustal densities, or a combination of these, is required to explain the gravity data.

\section{INTRODUCTION}

This investigation is one of a number of geophysical studies of basin structures along the Sierra Nevada. Combined with earlier studies, this paper completes the reconnaissance geophysical survey of all the major basins along the eastern front of the Sierra south of Mono Lake. These basin structures lie along the boundaries between three major geologic and physiographic provinces: the Sierra Nevada, the Basin and Range, and the Mojave Desert. The structure of the basins and the stratigraphy of the sedimentary deposits hold important clues to the tectonics of these three provinces and their relations to each other.

\section{Summary of previous geophysical work}

Gutenberg, Wood, and Buwalda (1932) con- ducted a pioneering seismic survey in this region to study the relation of valley sediments to the Sierran fault near Lone Pine, California. Pakiser, Press, and Kane (1961) conducted a combined gravity and seismic survey of Mono Basin. This work established the effectiveness of the combination of gravity and seismic methods in this regicn using the seismic techniques to establish depths to basement at selected points within the basin and the gravity to extend the results of the seismic survey. A startling structure was found underlying Mono Lake. This structure is a circular basin with steep sides extending to depths of $18,000 \mathrm{ft}$. The structure was interpreted as a volcanic-collapse feature.

Pakiser (1961) reported on results of a gravity survey in Long Valley that revealed a deep basin of similar structure to Mono Basin. Kane and

† Contribution No. 1136, Division of Geological Sciences, California Institute of Technology. Presented at the Thirtieth Annual SEG International Meeting, November 9, 1960. Manuscript received by the Editor November 20,1963 .

* U. S. Geological Survey, Denver, Colorado.

$\ddagger$ Seismological Laboratory, California Institute of Technology, Pasadena, California. 
Pakiser (1961) reported on a gravity and seismic survey of southern Owens Valley. This survey revealed that Owens Valley is an elongated basin structure following the front of the Sierra Nevada with depths reaching $8,000 \mathrm{ft}$ in the vicinity of Owens Lake. Seismic-refraction results reported in the present paper support the general interpretation of Kane and Pakiser in this region.

This paper was followed by a paper (Pakiser and Kane, 1962) which extended the survey to cover northern Owens Valley and showed that the elongated basin structure of Owens Valley followed the front of the Sierra Nevada to a point about 20 miles north of Bishop, California.

Mabey (1956) reports on a gravity and seismic survey of Searles Lake, and Mabey (1960) reported an extensive gravity survey of the Mojave Desert. This last paper covers a large area bordering the regions studied in the present paper. An intensive geological and geophysical investigation of Indian Wells Valley and the surrounding ranges is in progress by the personnel at the Naval Ordnance Test Station, China Lake, California. Preliminary results of this investigation have been presented by von Huene (1960). Oliver, Pakiser, and Kane (1961) report the results of a gravity survey covering an extensive area in the central Sicrra Nevada. This paper shows the relation of the gravity anomalies in the High Sierra to the gravity ancmalies in the adjoining basins.

\section{GEOLOGIC SETTING}

\section{Physiography}

The Sierra Nevada is one of the major mountain ranges in the western United States. On the east, the range rises steeply to a high ridge containing peaks with elevations exceeding $14,000 \mathrm{ft}$. From this ridge the range slopes westward for about 60 miles in a ramplike structure which disappears under the Cenozoic deposits of the Central Valley of California. At the northern boundary, the Sierra structural block decreases in elevation and is terminated by volcanic rocks of the Cascade Range. At the southern boundary, the Sierra terminates abruptly at the Garlock fault which separates the Sierra Nevada from the Mojave Desert.

The physiography of the western part of the Mojave Desert is distinctly different from the physiography of the Sierra and the Basin and Range province which border it on the north. The boundary between the Sierra Nevada and the
Mojave Desert is a major fault zone, including the Garlock fault. This fault is a gently arcuate feature which is concave toward the south, and strikes approximately north 60 degrees east. The Garlock is a predominately strike-slip fault which can be traced from the San Andreas fault eastward to the Avawatz Mountains, where it appears to turn southwest with a zone of faulting from southern Death Valley. The southeast boundary of the Mojave is the San Andreas fault zone. This fault is one of the largest known faults and is part of the worldwide tectonic system surrounding the Pacific Ocean. The Mojave Desert lies in a triangle between these two major active faults-the Garlock and the San Andreas-but the advanced stage of geomorphic evolution and lack of evidence for recent large-scale faulting suggest that the Mojave block has been inactive.

Typical Basin and Range structures, which cover most of the state of Nevada, are characterized by elongated block-faulted mountains and basins. An east-trending line across the center of the province crosses about 15 range crests. The average distance from crest to crest of the ranges is about 20 miles, and the ranges are commonly 200 miles in length, trending nearly north. Trends of the ranges tend to shift parallel to the Sierra Nevada on the west.

The Sierra, Mojave, and the Basin and Range provinces show remarkable contrasts among each other, but each province shows a high measure of structural and physiographic consistency within its own boundaries. The boundaries between the provinces are major faults with lengths and displacements that suggest penetration into the mantle, but within the individual provinces the scale of the structural features suggests that the structural breaks may be confined to the crust.

\section{Rocks of the area}

Regional metamorphism in the Jurassic and Cretaceous periods has reduced the basement rocks in this area to a mass with relatively homogeneous seismic velocity and density. The preTertiary basement consists of granitic rocks typified by the Sierra Nevada batholith, and Paleozoic and Precambrian metamorphic rocks. This basement complex has apparently been uplifted and leveled and then faulted into the present Basin and Range structure. Cenozoic sediments were eroded and transported from the uplifted blocks to fill the basins. A section of these sedi- 
mentary deposits has been uplifted at the southern end of the area studied in the vicinity of Red Rock Canyon. Dibblee (1952) described the geology and stratigraphy in this area. The Ricardo formation of Pliocene age is composed of terrestrial sandstones, mudstones, and pebble conglomerate about 7,000 ft thick, and it is separated by an angular unconformity from the Goler formation. The Goler formation is of Miocene age and is composed of sandstones, mudstones, and pebble conglomerates about $6,500 \mathrm{ft}$ thick. The rocks of the Ricardo formation are loosely cemented; similar rocks in the Goler formation are more firmly cemented and probably have a higher seismic velocity and greater density. The Ricardo formation contains several basalt and andesite flows and localized deposits of pumice and tuff.

There are numerous exposures of Cenozoic volcanic rocks in the region. Most of the individual flows are basalt or andesite less than 200 or $300 \mathrm{ft}$ thick. Where the sources can be observed they almost invariably lie on the uplifted granitic rocks rather than within the basin sediments. In addition to the possible tectonic significance of this observation it supports the assumption used in the interpretation of the geophysical data that the basin structures are filled primarily with clastic sedimentary rocks.

\section{EVIDENCE FOR RECENT FAULTING}

C. R. Allen (written communication, Figure 1) has compiled a map of faults in the area based on surface geology. Scarps in the alluvium or in volcanic rocks can be found along most of the faults in Figure 1, indicating that these faults have been active in Pleistocene or Recent time. A major earthquake in 1872 resulted in motion along a fault in front of the Alabama Hills at Lone Pine. The motion along this fault had both vertical and horizontal components. Most observers agreed that the strike-slip and dip-slip components were about equal, but as a result of some confusion in the early observations, the direction of the strikeslip movement is in question. Hopper (1939) described faulting which cuts Pleistocene and volcanic rocks east of Rose Valley. The stratigraphic evidence described by Dibblee (1952) in the El Paso Mountains indicates that the entire El Paso Mountain block has been uplifted since early Pleistocene time. Putnam (1960) gave evidence for major Pleistocene uplift of the Sierra Nevada. He has mapped glacial deposits from four glacial stages in the vicinity of McGee Mountain on the eastern slope of the Sierra. Earlier glacial till representing the $\mathrm{McGee}$ stage lies at an altitude of $10,800 \mathrm{ft}$. Based on the displacements of the glacial deposits, Putnam estimates an uplift of 3,000 to 4,000 ft since McGee time. These pieces of geological evidence from diverse sources support the conclusion that the structural deformation of the region and the uplift of the Sierra Nevada have proceeded at an accelerated pace during the last few million years, and suggest that tectonic activity is continuing at the present time.

\section{Seismicity}

The California Institute of Technology has had a network of seismic stations in the region of the southern Sierra Nevada since 1934, and members of the Seismological Laboratory have compiled a listing of the earthquakes occurring between 1934 and 1956. All earthquakes in this listing larger than magnitude 4 are plotted in Figure 2. Different symbols are used to designate earthquakes with magnitude 4 to 5 , magnitude 5 to 6 , magnitude 6.1 , and earthquake swarms. Earthquake swarms appear to be a characteristic feature in this region. As many as one hundred small earthquakes may occur within a limited region in a few days or weeks. Some of these swarms have a main shock with associated foreshocks and aftershocks; but other swarms have no shock large enough to qualify as a main shock. Swarms of this type are characteristic of volcanically active areas.

There are not enough seismic stations in the region to get satisfactory fault-plane solutions for the smaller shocks. Richter (1960) reported on two series of small earthquakes in this area near Haiwee and near China Lake. He reports that initial compressions and dilatations in both groups of shocks were consistent, but gave no simple fault-plane solutions. The lack of a sufficient number of seismic stations prevents accurate determinations of focal depths. A depth of $16 \mathrm{~km}$ was assumed in the routine calculations and appears to give satisfactory locations. We can conclude from this only that the earthquakes in the area are probably within the crust. An error in the assumed depth can usually be compensated by an error in the origin time for earthquakes above the mantle. A more precise determination of focal depths was made in connection with the analysis of the aftershocks of the 1952 Kern County earthquake (Richter, oral communication). Focal 


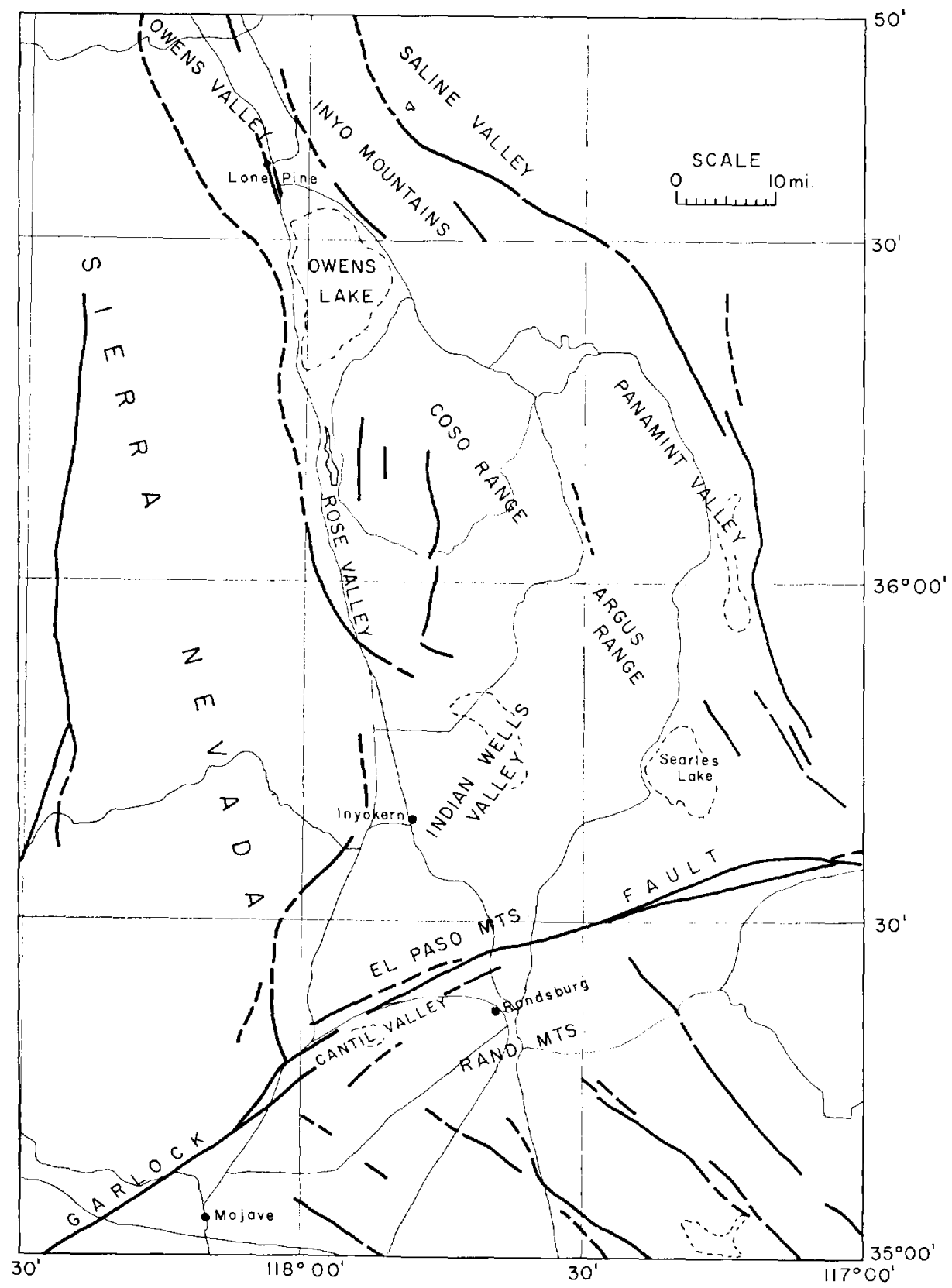

Fig. 1. Fault map from C. R. Allen. 


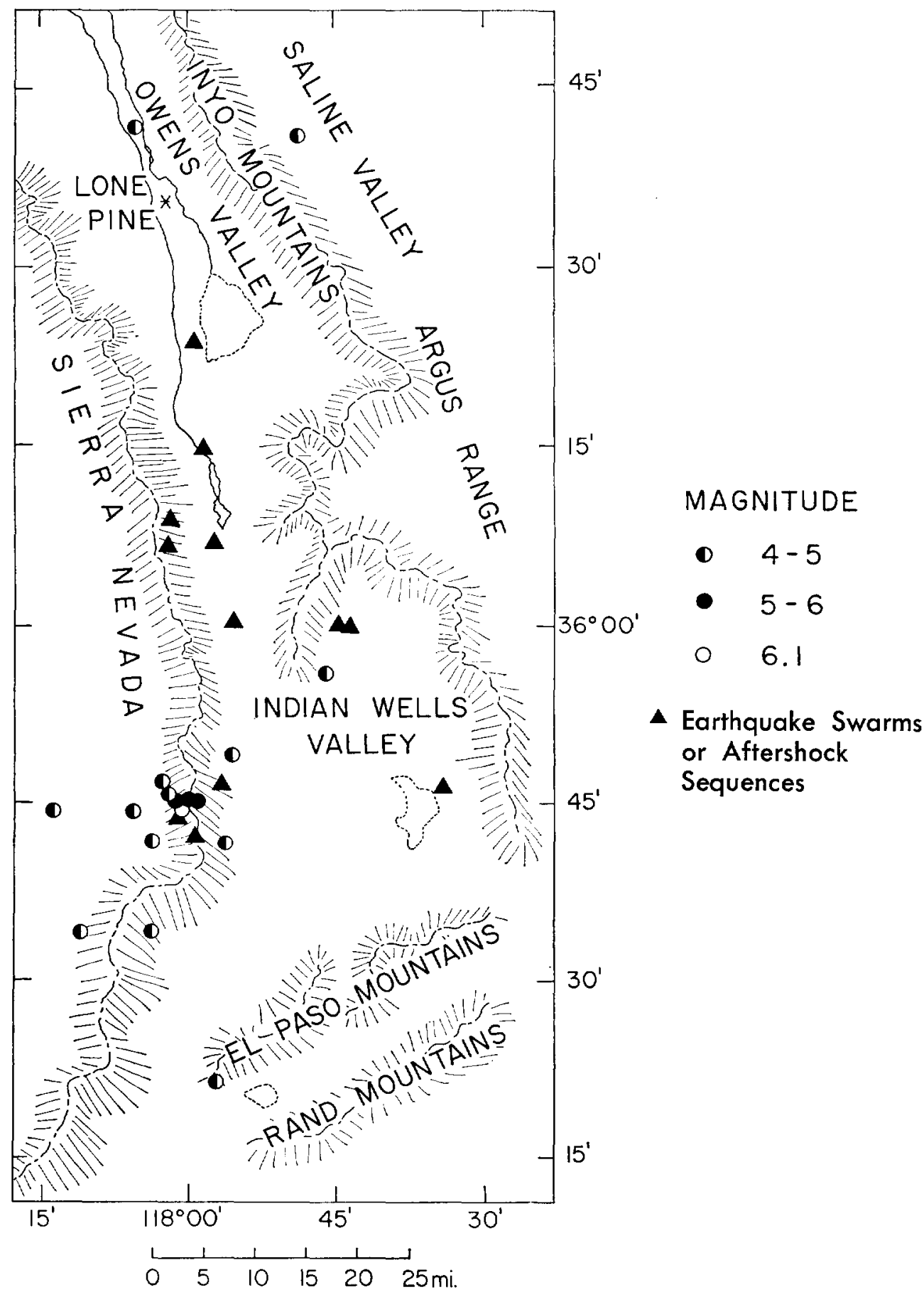

FIg. 2. Seismicity map magnitude. 
depths of these shocks tended to lie in a depth zone between 10 to $20 \mathrm{~km}$, but uncertainties in velocities prevented a precise depth determination. Many possible hypotheses are suggested by the data on earthquakes in this area; but the density of stations is not sufficient to determine the exact location, depth, and radiation patterns.

The largest recorded seismic event in the region was the 1872 earthquake at Lone Pine. Vertical displacements of 10 to $20 \mathrm{ft}$ and horizontal displacements of up to $13 \mathrm{ft}$ were reported. Unfortunately, there is disagreement about the horizontal displacement. Richter (1958) gives a good summary of the known facts in published reports. The story is obviously complex and has been seriously confused by inadequate early observations, followed by detailed observations many years after the event. Despite these difficulties, certain important facts can be established. This was a major earthquake, undoubtedly exceeding magnitude 8 , with vertical and horizontal displacements exceeding $10 \mathrm{ft}$. Vertical movement on the fault was consistent with the present topography; repeated movements of this nature would account for the mountain and basin structures in the area. Much of the direct evidence of the faulting was eliminated in the 35 years between 1872 and 1907 when the earthquake area was studied in detail by Johnson (Hobbs, 1910), and we may conclude that many faults of this magnitude could have occurred in recent prehistoric time without leaving easily recognizable surface evidence.

\section{SEISMIC-REFRACTION SUR VEY}

\section{Field operations}

Eighteen seismic-refraction profiles (Figure 3 and Table 1) were recorded along the eastern front of the Sierra Nevada to determine the thickness of sediments in the basins bordering the range. These profiles were recorded in the summers of 1958 and 1959 by a crew from the Seismological Laboratory of the California Institute of Technology. An eight-channel recording system with Texas Instruments Inc.'s two-cycle geophones and United Geophysical Company's low-frequency refraction amplifiers was used for recording. Shot holes were drilled by hand auger during the first field season and by a shot-hole rig contracted at cost from Western Geophysical Company during the second field season.

The field operations were designed to yield maximum coverage in the limited time and with the limited funds available. To achieve this end a field technique that gives the effect of a reversed profile without actually reversing the geophone spread was used (Dix, 1952, p. 263). With this method the geophone spread is left stationary while the shotpoint is moved. The apparent velocity across the spread is compared with the apparent velocity measured from a plot of the traveltimes from the first geophone to the shotpoints. This technique proved to be well suited for the preliminary study of basin structures.

Drilling conditions limit the area that can be

Table 1. Summary of seismic velocities and depths

\begin{tabular}{|c|c|c|c|c|c|c|c|c|}
\hline \multirow{2}{*}{ Profile } & \multicolumn{7}{|c|}{$\begin{array}{l}\text { Seismic velocities } \\
(\mathrm{ft} / \mathrm{sec})\end{array}$} & \multirow{2}{*}{$\begin{array}{l}\text { Depth } \\
\text { (in ft) }\end{array}$} \\
\hline & $V_{0}$ & $V_{1}$ & $V_{2}$ & $V_{3}$ & $V_{4}$ & $V_{5}$ & $V_{6}$ & \\
\hline 1 & & 7,000 & & & 10,000 & & & \\
\hline 2 & & 6,200 & & & 8,600 & & 15,800 & $2,200-7,000$ \\
\hline 3 & & 5,040 & 6,100 & 7,600 & 9,600 & & & - \\
\hline 4 & & 5,800 & 6,900 & & 8,800 & & 15,900 & $1,300-8,000$ \\
\hline 5 & 2,000 & 5,900 & & & & & 16,500 & 2,000 \\
\hline 6 & 4,900 & & & & 8,000 & 11,500 & 15,400 & 5,900 \\
\hline 7 & 3,800 & 5,700 & & & & 11,750 & 15,500 & 2,800 \\
\hline 8 & & 6,000 & & & & & 15,500 & 1,300 \\
\hline 9 & 2,400 & & & 7,180 & & & & \\
\hline 10 & 2,400 & & & 7,180 & & & 15,050 & 2,120 \\
\hline 11 & 2,000 & 6,000 & & & 9,800 & & 16,600 & 6,000 \\
\hline 12 & 3,700 & & & 7,750 & 9,400 & 11,400 & 14,400 & 5,100 \\
\hline 13 & 4,650 & & & & 9,500 & & $15,100 ?$ & $5,000 ?$ \\
\hline 14 & 3,200 & 5,700 & & 7,780 & 9,200 & & 16,000 ? & 6,000 \\
\hline 15 & 2,000 & 6,480 & & 7,920 & 9,180 & 12,080 & 16,000 & $7,700 ?$ \\
\hline 16 & 4,000 & 6,240 & & & 9,200 & 12,160 & 17,000 & 6,800 \\
\hline 17 & 2,080 & 5,760 & 6,720 & & 8,940 & & 16,240 & 5,900 \\
\hline 18 & 3,350 & 6,580 & & 7,700 & & 10,320 & 16,620 & 7,400 \\
\hline
\end{tabular}




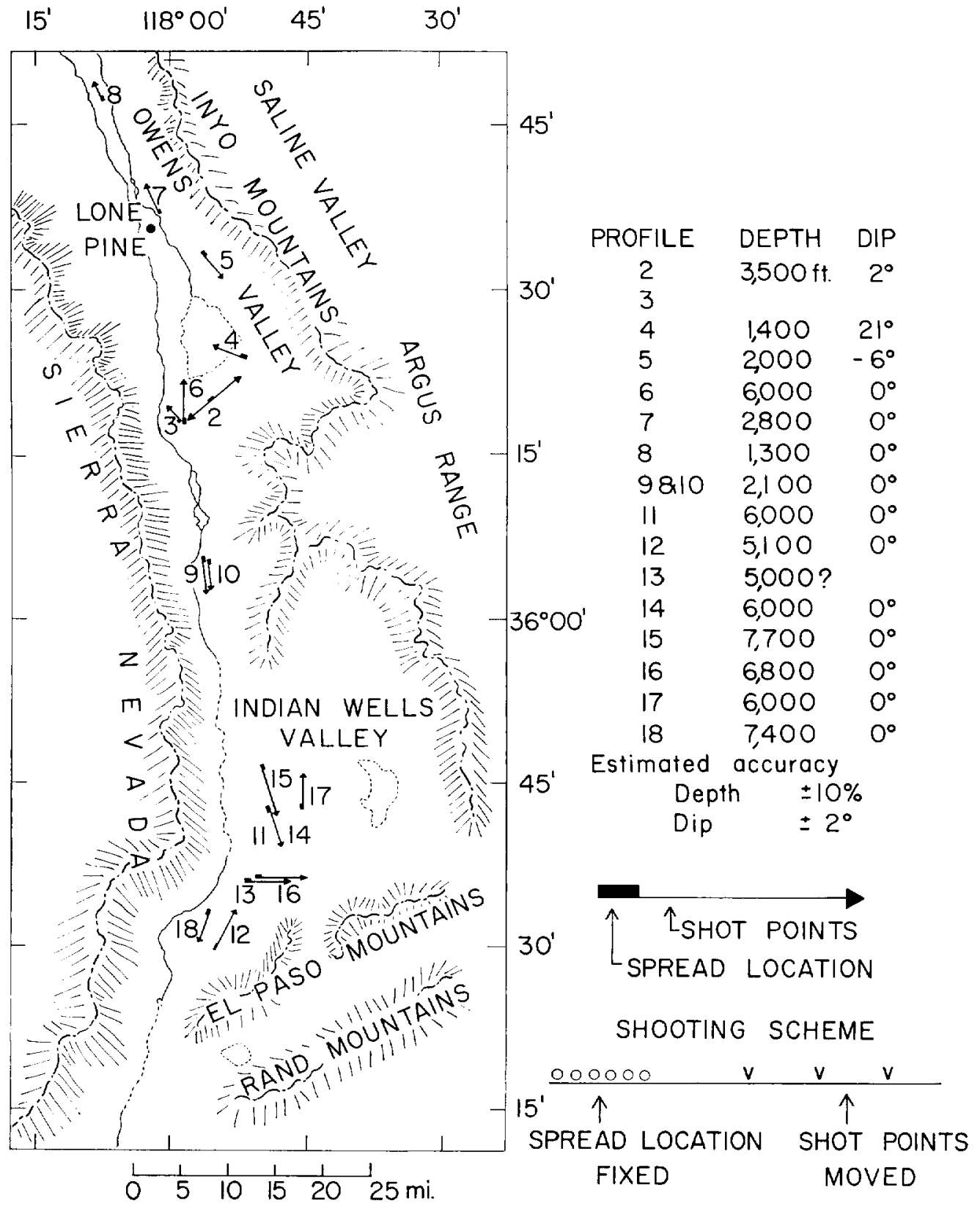

FIG. 3. Location of seismic-refraction profiles. 


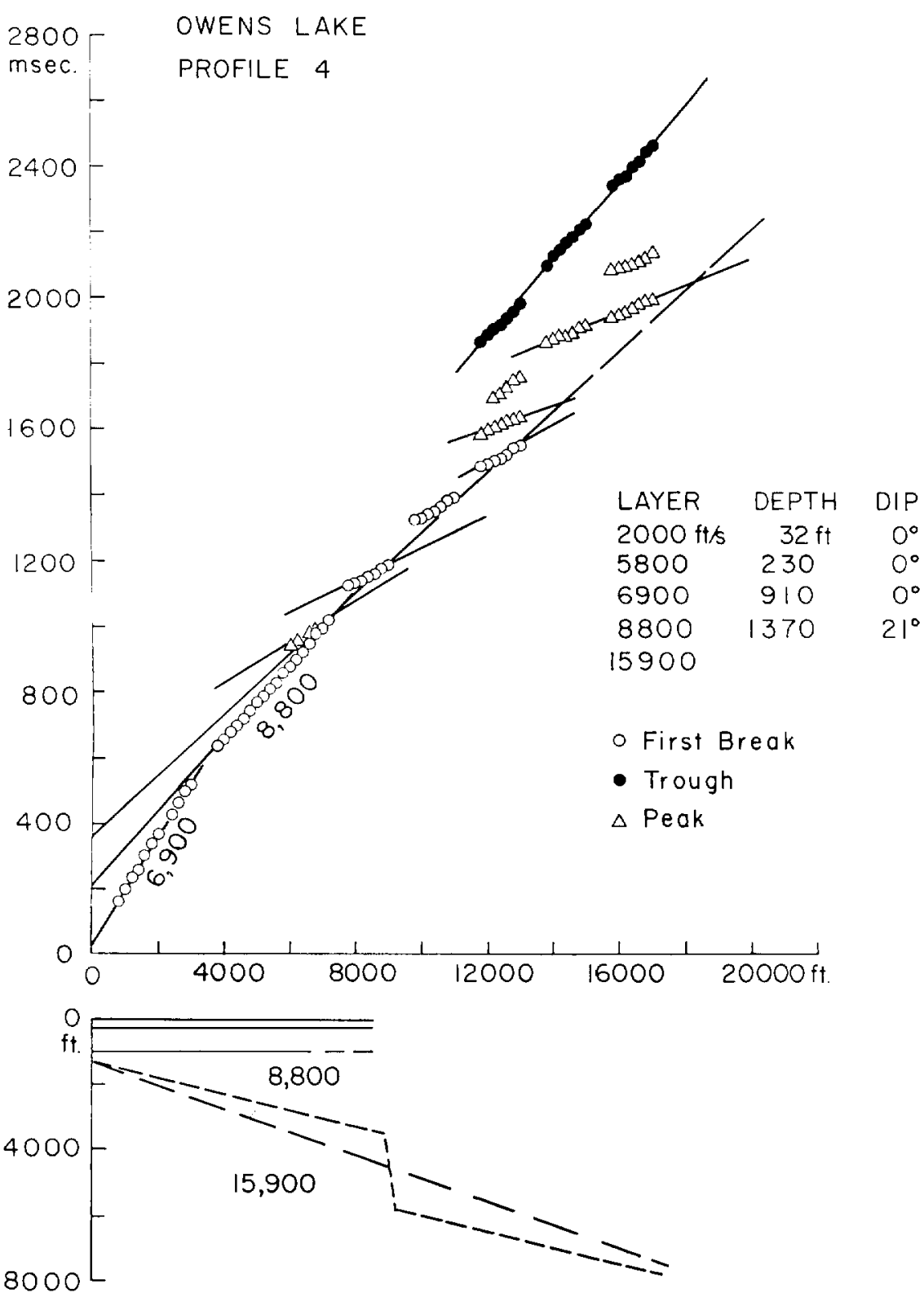

FIG. 4a. Representative traveltime plots.

studied and are the predominant factor in record quality. Three types of terrain were encountered: high fans, low fans, and dry lakes; and each type of terrain had characteristic drilling problems. The high fans were near the mountain front and consisted of poorly sorted debris, including large boulders. It was practically impossible to obtain a satisfactory shot hole in this material. The low fans were farther from the mountain front and consisted mainly of sands and gravels. Usually it was not possible to reach the water table with a shot hole in the low fans, but fairly good energy coupling could be obtained with shallow holes just deep enough to prevent blow-out. The use of drilling mud was necessary to prevent cave-in. The desert lake terrain is frequently found in the 

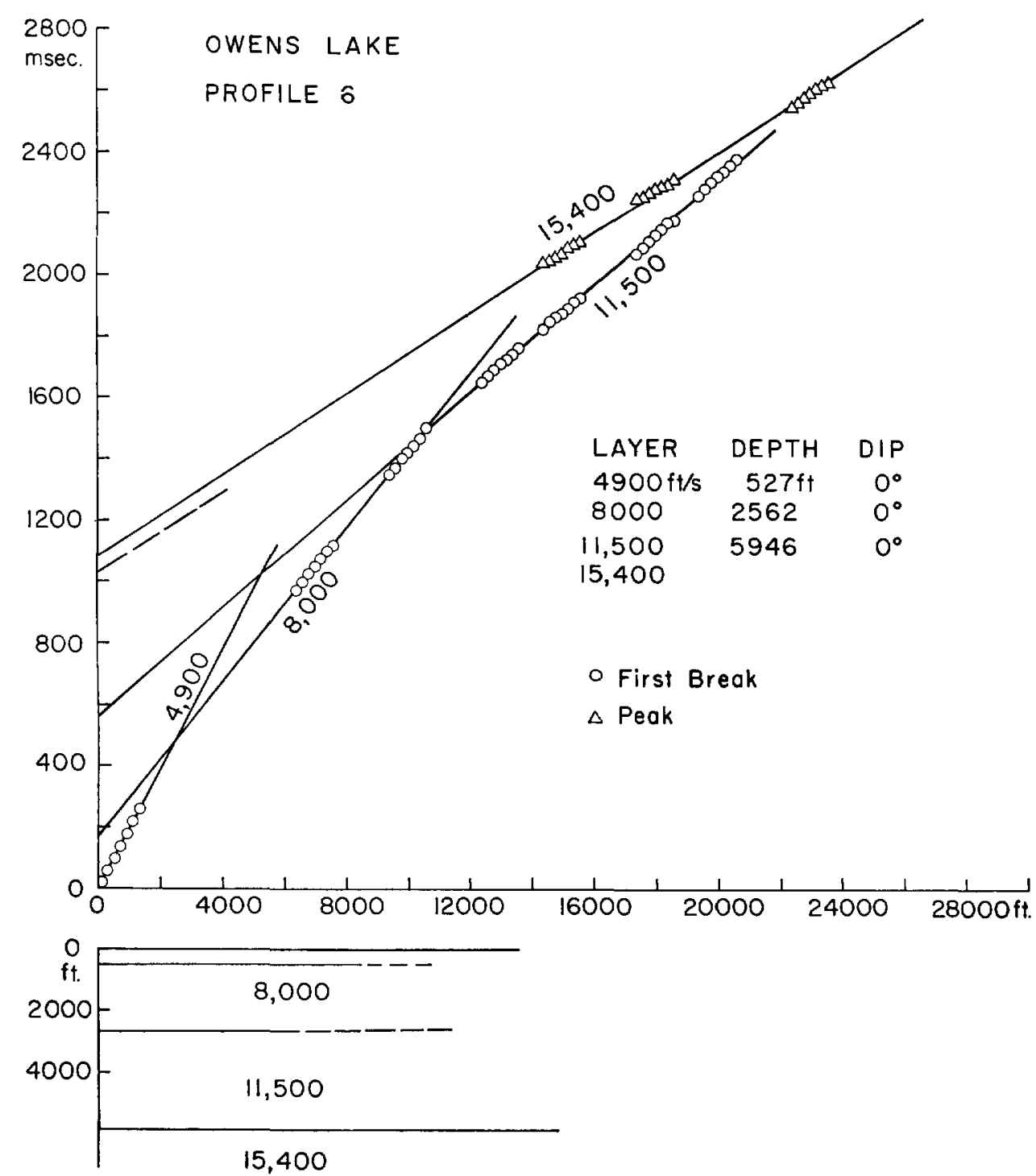

FIG. 4b. Representative traveltime plots.

central part of the basins in this area. Lake deposits consist mainly of fine muds, and the water table is near the surface. Shot holes drilled into the water table provided excellent energy coupling and could be drilled easily where the surface of dry lake beds would support drilling equipment.

\section{Interpretation of seismic profiles}

Each profile was interpreted separately without regard to velocities and depths measured at near- by profiles or to evidence from the gravity data. Therefore, any velocity correlations between profiles are not the result of the carry-over of information from one profile to another. Samples of the traveltime curves with their interpretations are shown in Figure 4. A complete set of traveltime curves has been presented (Healy, 1961). A section of typical records corresponding to the traveltime plot of Figure 4a is shown in Figure 5. Profile 2 was recorded in cooperation with the U. S. Geological Survey, and the interpretation of the pro- 


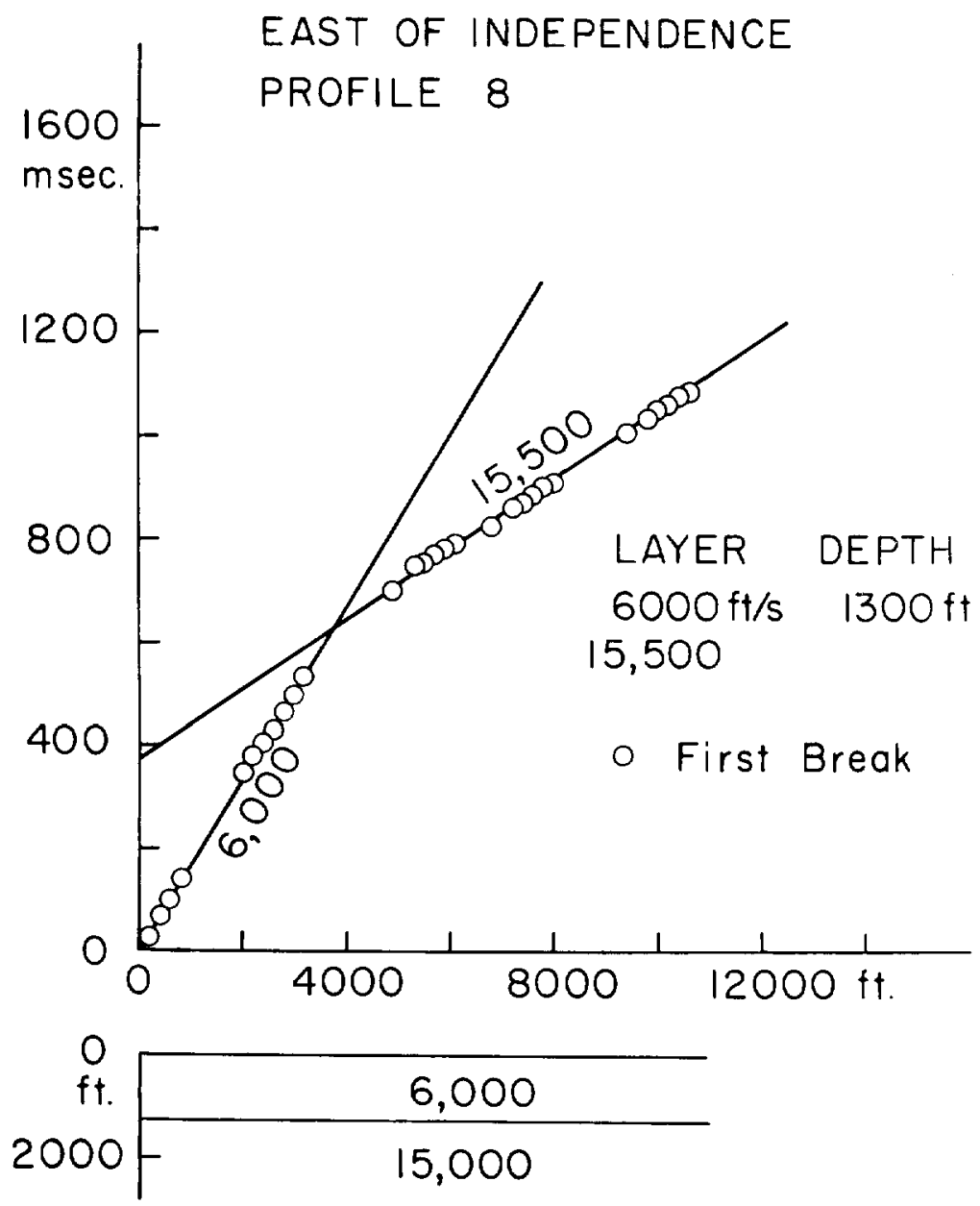

Fig. 4c. Representative traveltime plots.

file was by L. C. Pakiser (written communication), (Kane and Pakiser, 1961). The remainder of the profiles were interpreted by the authors. As mentioned above, the geophone spread was fixed and the shotpoint was moved. The traveltime between the first geophone and the shotpoint was plotted against the corresponding distance to give a standard refraction plot. Then the arrival times at the remaining geophone positions were plotted on the same graph at points located with respect to the first geophone. The initial plot gives the apparent velocities from the spread toward the moving shotpoints, and the observed velocities across the spread give the reversed apparent velocity. With this method of plotting, a dipping layer will have an en-echelon pattern on the traveltime plot (Figure 4a). The error in the true velocities of Table 1 does not exceed 10 percent; the error in the indicated depths is probably less than 10 percent, provided no velocity inversions occur in the section.

Dips are determined with an an accuracy of two degrees or three degrees. It is assumed that the high-velocity layer $(15,000$ to $16,000 \mathrm{ft} / \mathrm{sec})$ is basement composed of granitic or metamorphic rocks similar to those exposed in the mountains bordering the basins. Pleistocene and Recent sediments exposed at the surface have velocities ranging from 5,000 to $7,000 \mathrm{ft} / \mathrm{sec}$ when saturated with water and from 1,500 to $3,000 \mathrm{ft} / \mathrm{sec}$ when they lie 


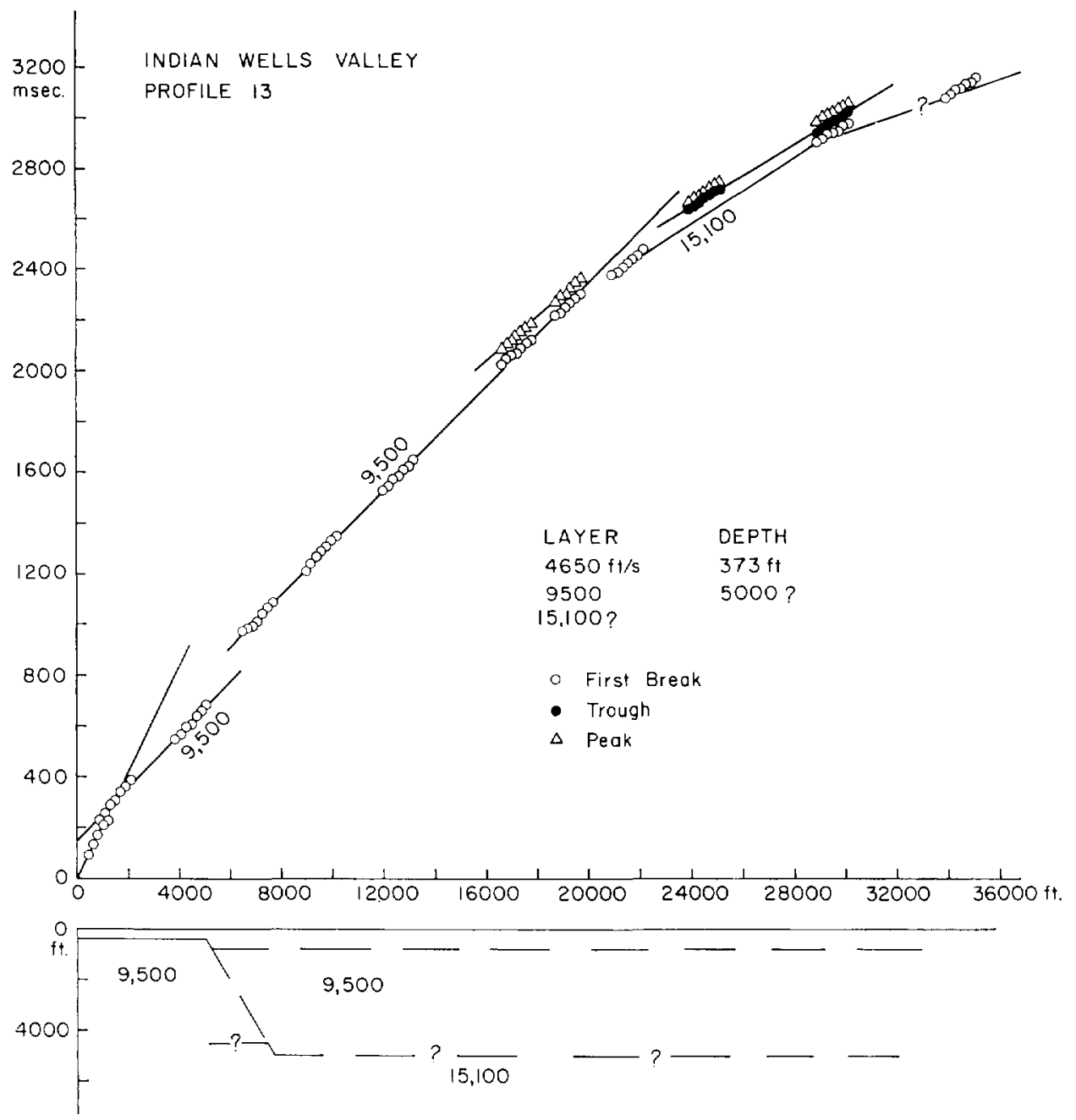

FIG. 4d. Representative traveltime plots.

above the water table. Intermediate layers have velocities ranging from about $8,000 \mathrm{ft} / \mathrm{sec}$ to $12,000 \mathrm{ft} / \mathrm{sec}$, and it is assumed that these layers are older and more compacted early Pleistocene or Tertiary sediments.

\section{Summary of seismic velocities}

Table 1 is a summary of seismic velocities and depths to basement for 17 profiles. The velocities were divided into seven categories $V_{0}$ through $V_{6}$. $V_{0}$ includes all velocities less than $5,000 \mathrm{ft} / \mathrm{sec}$. Velocities in this range are associated with a thin surface layer above the water table.

The $V_{1}$ layer lies immediately below the surface layer. Velocities in the $V_{1}$ layer range from 5,040 to $6,580 \mathrm{ft} / \mathrm{sec}$ with an average velocity of 5,950 $\mathrm{ft} / \mathrm{sec}$. These velocities are associated with unconsolidated water-saturated sediments.

Some of the entries in columns $V_{2}$ and $V_{3}$ may result from conventionally interpreting a gradual increase in velocity with depth as a series of step increases. However, certain entries in column $V_{3}$ are based on distinct breaks in the traveltime curve, suggesting a layer with velocity of about $7,500 \mathrm{ft} / \mathrm{sec}$.

The average of the velocities in column $V_{4}$ is $9,110 \mathrm{ft} / \mathrm{sec}$. The velocities range from 8,000 to $9,800 \mathrm{ft} / \mathrm{sec}$. All of these velocities represent dis- 

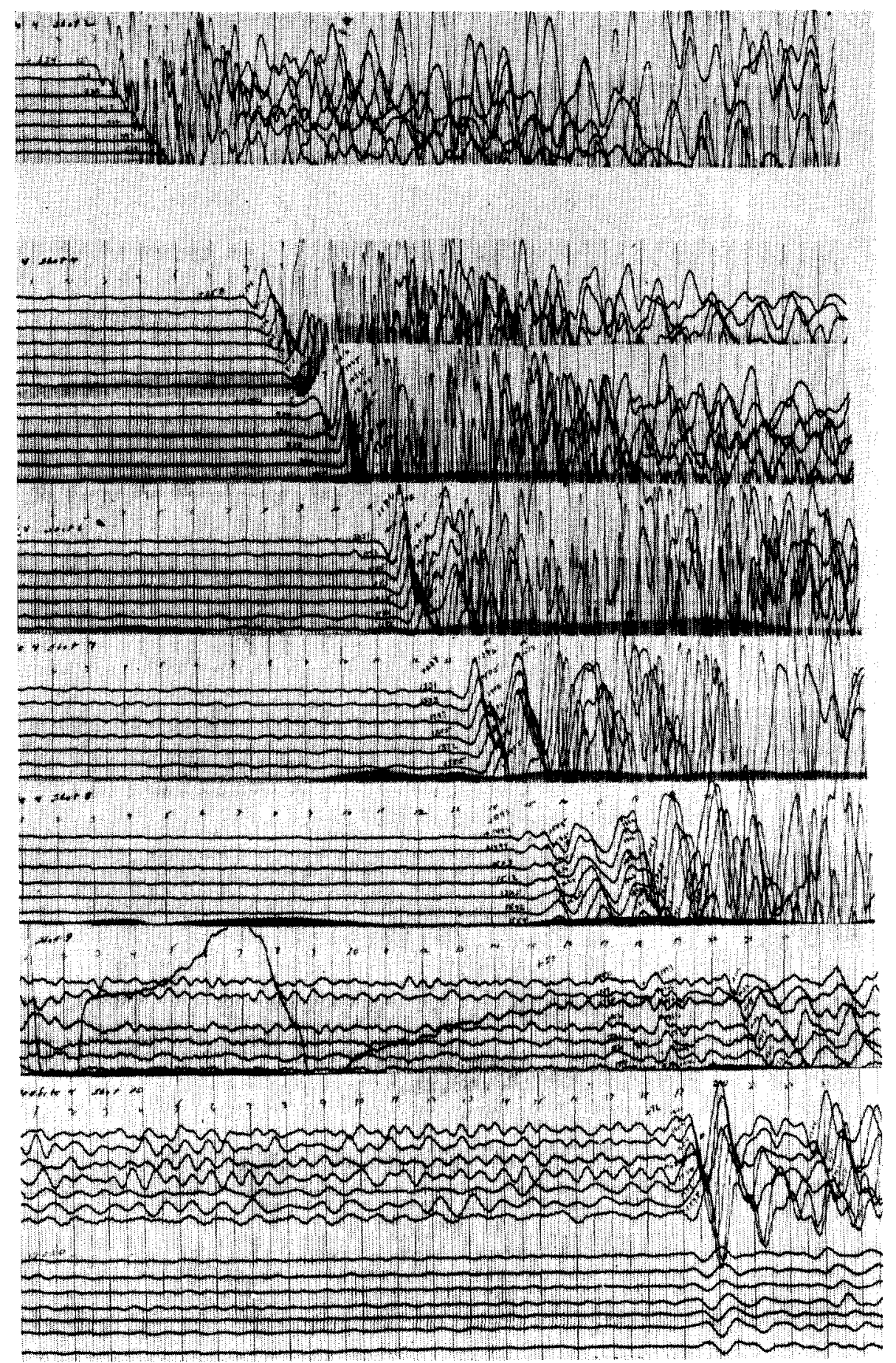

FIG. 5. Seismograms from profile 4. 
tinct breaks in the traveltime curves, suggesting that this range results from a regional stratigraphic change.

The velocities in column $V_{5}$, ranging from 10,320 to $12,080 \mathrm{ft} / \mathrm{sec}$, probably represent older Tertiary sedimentary rocks. The break between velocities $V_{4}$ and $\boldsymbol{V}_{5}$ may correspond to the unconformity between Miocene and Pliocene sedimentary deposits mapped by Dibblee (1952) in the Saltdale quadrangle.

The basement velocities are designated as $V_{6}$. The average of the basement velocities is 15,840 $\mathrm{ft} / \mathrm{sec}$. The basement velocities are distinctly greater than any velocities measured in the sedimentary section.

\section{GRAVITY SURVEY}

\section{Gravity field methods and error estimation}

Twelve hundred gravity stations were established along the eastern Sierra from Owens Lake to the Garlock fault and along the southern Sierra between Johannesburg and Mojave. These observations were made during the summer of 1959 and during January and February of 1961.

Errors in reading the meter were checked by repeated readings at the same point and were found to be less than $0.1 \mathrm{mgal}$. Drift and tide effects were not greater than $0.5 \mathrm{mgal}$ during a traverse, and error from this source is estimated at less than $0.2 \mathrm{mgal}$. The maximum error in observed gravity is estimated to be less than 0.3 mgal.

If a location is wrong by $1,000 \mathrm{ft}$ in latitude it will result in an error of 0.3 mgal in the Bouguer anomaly, Most stations are located within $500 \mathrm{ft}$. A few stations may be in error by $1,000 \mathrm{ft}$, so the maximum error from this source is $0.2 \mathrm{mgal}$.

An error in elevation of $20 \mathrm{ft}$ would result in an error in the Bouguer anomaly of $1.2 \mathrm{mgal}$. About one quarter of the stations were at points of elevation known to better than two feet. The remainder of the stations were determined by altimeter. In the basins, altimeter measurements yielded elevations accurate to within 10 feet, as indicated by ties and repeated stations. On long lines in to the mountains, accuracies decreased, but the maximum error is estimated not to exceed $20 \mathrm{ft}$ except on two exceptionally long lines in Jawbone Canyon and Nine Mile Canyon where the error may be $30 \mathrm{ft}$.

Almost all stations have an error in terrain cor- rection less than $0.5 \mathrm{mgal}$. A few stations in very precipitous terrain, as in Nine Mile Canyon, may have a maximum terrain correction error of 2.0 mgal. The maximum errors are estimated in Table 2. It is estimated that 95 percent of all stations are accurate to within one mgal. A few stations with both rugged topography and poor elevation control may have errors approaching 4 mgal.

Table 2. Sources of error

\begin{tabular}{lcl}
\hline & $\begin{array}{c}\text { Expected } \\
\text { maximum } \\
\text { error }\end{array}$ & $\begin{array}{c}\text { Absolute } \\
\text { maximum } \\
\text { error }\end{array}$ \\
\hline Observed gravity & $0.2 \mathrm{mgal}$ & $0.4 \mathrm{mgal}$ \\
Location & 0.1 & 0.2 \\
Elevation & 0.6 & 1.2 \\
Terrain correction & 0.5 & 2.0 \\
\hline Total & $1.4 \mathrm{mgal}$ & $3.8 \mathrm{mgal}$ \\
\hline
\end{tabular}

\section{Gravity reductions}

Gravity values were reduced to the complete Bouguer anomaly. Elevations were multiplied by 0.5998 to reduce the gravity readings approximately to the equivalent reading at sea level. Corrections for the curvature of this infinite sheet were made from the table in Swick (1942) giving Bullard's correction B.

Corrections for latitude were extrapolated from the table in Swick giving values of gravity as a function of latitude from the international gravity formula.

Terrain corrections were calculated on the Bendix G15 computer using a density of 2.67 out to a distance of 14 miles. The effects of topography very near the station were generally neglected.

\section{Gravity interpretation}

Gravity interpretation for two-dimensional bodies was carried out by two methods: a method of direct integration proposed by Talwani et al (1959), and a method of automatic interpretation similar to one described by Bott (1960). The method of automatic interpretation proved to be the more efficient. In Talwani's method the line integral around a closed polygon is evaluated as the sum of the contributions due to individual sides of the polygon. A basic instability in this method occurs when the observation point is in line with a side of the polygon. 


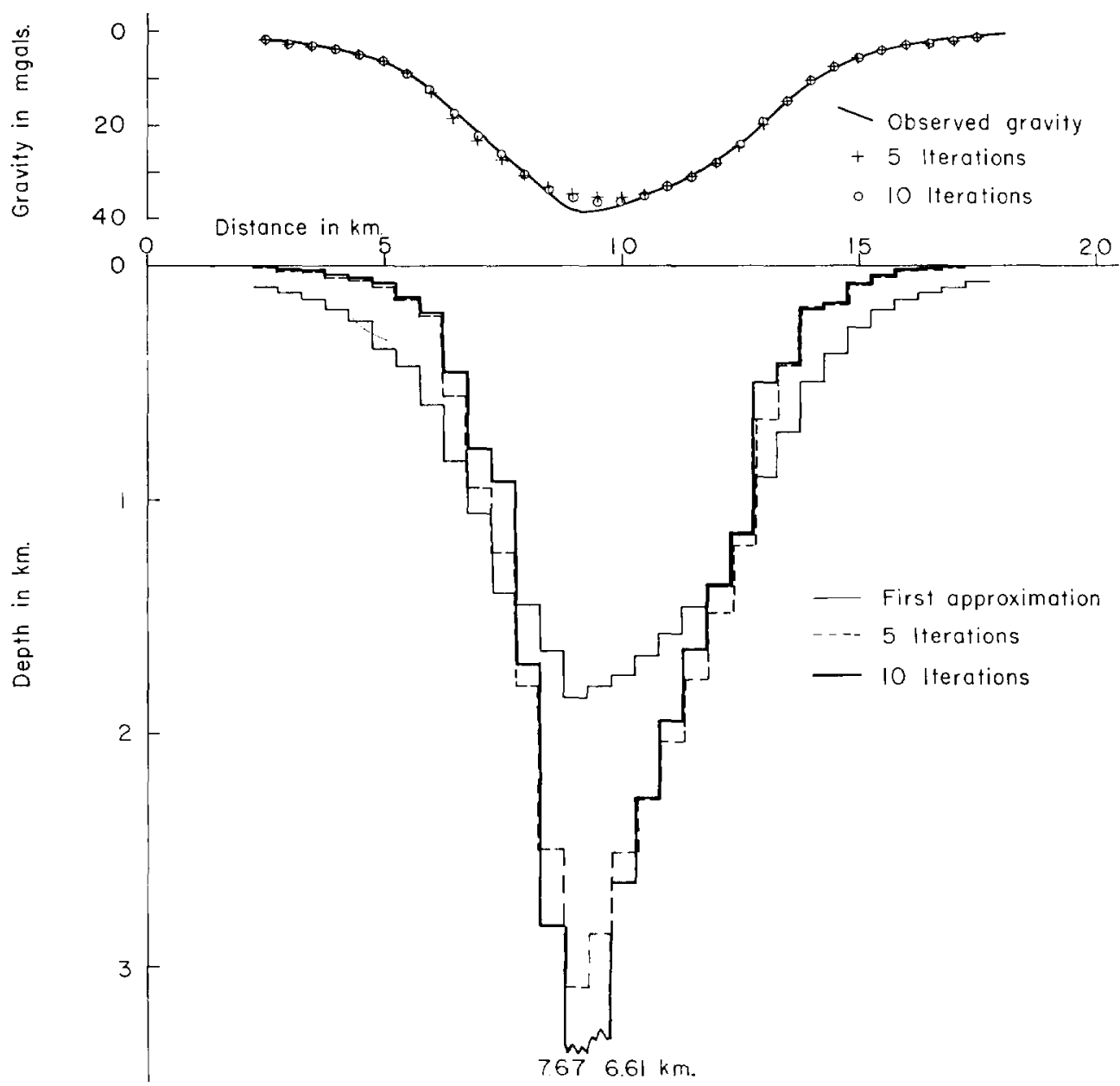

$F_{I G}$. 6. Convergence of iterative gravity interpretation.

This difficulty might be avoided by testing before each computation and taking additional steps to avoid the instability.

An automatic method for interpretation of twodimensional anomalies was developed for the Bendix G15 computer. The anomalous body is approximated by rectangles, and the type of instability encountered in Talwani's program is avoided by fixing the location of the stations at the center points of the upper sides of the rectangles.

The first step is to plot the measured anomaly and the extent of the basin. Anomaly values are then picked from the plot at equal intervals. The regional gradient is removed from these gravity values, and the residual values are used for the input to the program.
The program computes the first approximation by taking each interval gravity value and computing the thickness of an infinite horizontal sheet that would produce an anomaly equal to the gravity anomaly at that point. This thickness is taken as the depth to the bottom of a rectangular prism underlying the gravity station. The calculation is repeated until a depth is assigned for prisms underlying all gravity stations (Figure 6).

The next step is to calculate the anomaly for the trial body, subtract the calculated anomaly from the observed anomaly to obtain a residual (which can be positive or negative), and from this compute a perturbation to the prism equal to the thickness of an infinite sheet that would give each residual. Each thickness is then added algebraically to the initial trial body. Gravity is recalcu- 


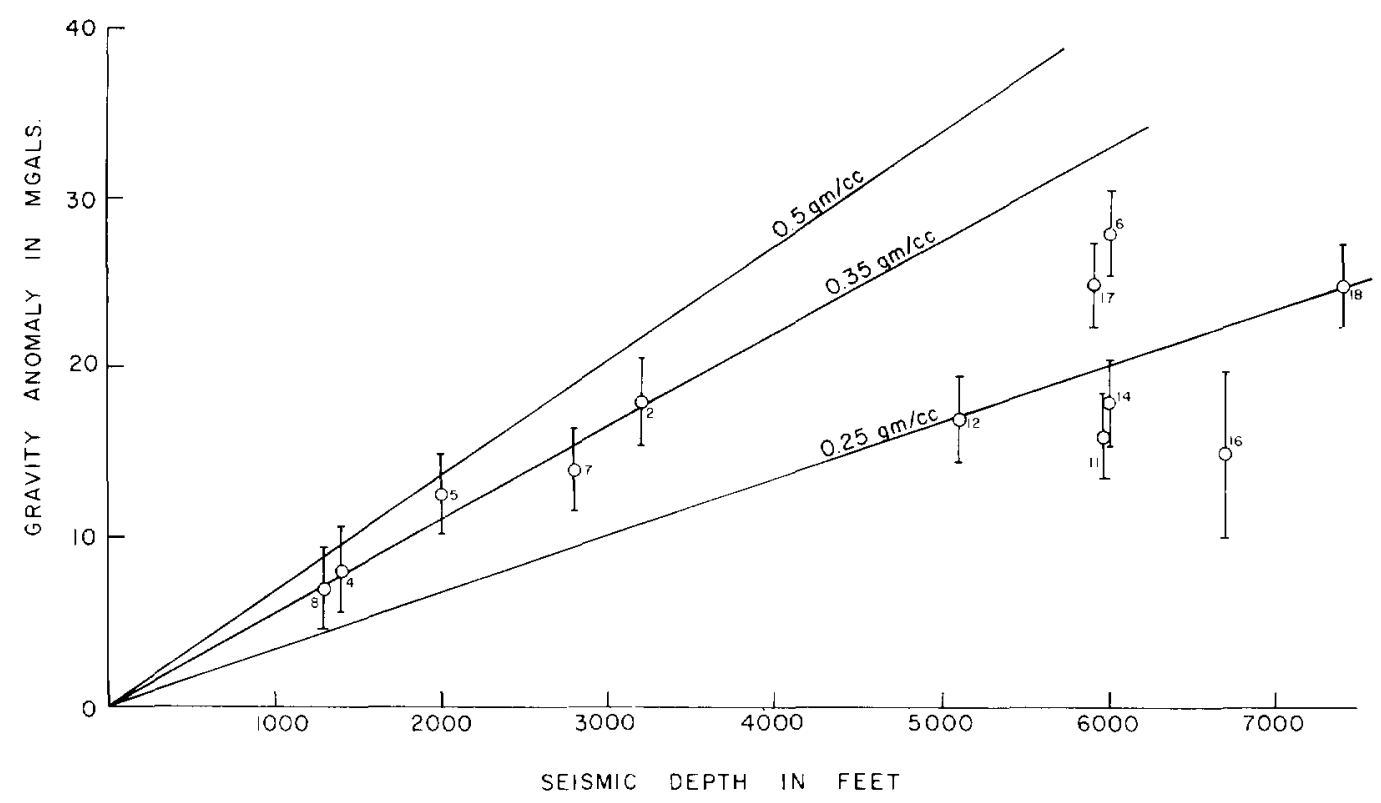

FIG. 7. Seismic depth vs gravity anomaly.

lated for the new trial body, and the process is repeated as many times as needed to fit the observed gravity.

Figure 6 shows the operation of this computation over a trial structure. The trial profile is Mabey's profile over Cantil Valley (Mabey, 1960). A density contrast of $0.5 \mathrm{gm} / \mathrm{cc}$ was used in this calculation and it was not possible to fit the observed gravity with this density. The two prisms at the center of the body would continue to increase their depths with each iteration, trying to match the curve at the center of the anomaly.

\section{Density}

Kane and Pakiser (1961) and Mabey (1960) have measured the densities of igneous and metamorphic rocks in this region and examined measurements by other investigators. They conclude that the standard crustal density of 2.67 is a good average for the region. There are rocks with densities that differ by $0.2 \mathrm{gm} / \mathrm{cc}$ from this standard value but most of the rocks composing the basement complex lie within $0.1 \mathrm{gm} / \mathrm{cc}$ of the standard crustal density.

The densities of the sedimentary rocks are more difficult to determine. Mabey (1960) uses an average density contrast between sediments and basement of $0.4 \mathrm{gm} / \mathrm{cc}$ but finds considerable variation in density between basins and, in some cases, large density variations within basins. Kane and Pakiser (1961) used a density contrast of $0.5 \mathrm{gm} /$ cc in Owens Valley and obtained reasonable agreement with the seismic data.

It is probable that density variations in the sediments are reduced with increasing age and depth of burial. Since all the sediments come from similar parent rocks, the primary cause of density variations arises from differences in porosity.

Increasing depth of burial and age of the sediment will decrease the porosity and probably eliminate erratic density variations observed at the surface.

The best available method for appraising the density parameter in this area is the correlation of gravity anomalies with depths determined from refraction-seismic work. Figure 7 is a plot of gravity anomaly versus seismic depth.

The gravity anomaly plotted is the difference in Bouguer anomaly (adjusted for regional gradients) between the location of the scismic profile and nearby basement outcrops. The straight, solid lines in the figure are the gravity anomalies of infinite sheets having the indicated density contrasts. The gravity anomalies are plotted with circles centered on vertical lines that show the estimated error in the gravity value.

As the depth of the structure increases, the width usually decreases proportionately, so that 
the density differences indicated will be less than the densities plotted for an infinite sheet. As depth increases, the indicated density difference will tend to decrease because of the expected increase of density of the sedimentary rocks with depth, and there will also be a decrease in the indicated density because the infinite sheet approximation becomes inadequate. In Figure 7, showing the relation between seismic depth and gravity anomaly, there is an apparent increase of density with depth. The greatest depth plotted is for profile 18 . When this seismic profile is compared with the gravity interpretation, we find that the gravity anomaly is explained by a density contrast of 0.35 . Thus, it appears that a large part of the apparent increase of density with depth would disappear if the gravity values were corrected for the limited extent of the structures as compared to infinite sheets. When allowance is made for this effect, a density contrast between 0.3 and 0.4 gives good agreement between seismic depth and gravity anomaly.

\section{Gravity contour map}

The gravity contour map is presented in Figure 8. The contours on the northernmost three or four miles on the map are supported by Kane and Pakiser's (1961) published map. South of the Garlock fault the contour map is extended by use of Mabey's data, especially in the region of Cantil Valley. Adjustments of about two mgal were necessary to join the data taken by the authors to the data of the other surveys mentioned above. These adjustments arise from the use of different base stations and the omission of the correction for the curvature of an infinite slab by the other investigators.

All the gravity stations shown on Figure 8 were occupied by the authors. Stations occupied by Mabey or by Kane and Pakiser are not shown on this map.

Four stations just off the western edge of the map lend additional support to the contours 860 through 875 .

The most prominent features on the gravity map are the gravity lows associated with Cenozoic deposits. These anomalies coincide with topographic lows which are bounded by uplifted mountain blocks. Reference to the fault map (Fig. 1) shows that these gravity anomalies tend to parallel major faults. The nature of the gravity lows will be examined in detail.

On closer examination the map reveals pronounced regional gradients with Bouguer anomaly values decreasing at two or three mgal per mile toward the north or northwest. A gradient is apparent across Cantil Valley between the Rand Mountains and the El Paso Mountains. Mabey's map of the Mojave Desert shows no significant regional gradients except on the boundaries of this province. Thus, in this region the Garlock fault apparently divides a province with a uniform crustal structure from a province with markedly different crustal structure.

A profile running northwest from the El Paso Mountains across the oval-shaped gravity low and to the closed 880 -mgal contour would show only a small regional gradient. However, if we continue this profile a few more miles to the northwest, it crosses a regional gradient of about three mgal per mile. These sharp changes in the regional gradients suggest that the source of the gradients is at relatively shallow depths in the crust.

In the vicinity of Little Lake, the granitic rocks are continuous or covered by only a thin veneer of sediments across the valley floor, so there is essentially no contribution to the anomaly from the Cenozoic sediments. South of Little Lake, there is no apparent regional gradient. North of Little Lake, the steep gradient in to Rose Valley results from an increasing thickness of Cenozoic deposits combined with a steep, north-trending regional gradient.

Gravity profiles interpreted by the automatic interpretive program are presented in Figures 9 and 10 . These figures show the position of the profiles with respect to the coordinates of latitude and longitude and the trace of the contact between Cenozoic and pre-Tertiary rocks. The broken horizontal lines indicate the rectangles used to approximate the anomalous body as explained above. The solid line is a geologic interpretation that would give approximately the same gravity anomaly as the series of rectangles used in the computation.

The gravity profiles plotted in the figures are "measured" gravity taken from the gravity-contour map. The computed gravity values fall within $0.2 \mathrm{mgal}$ of the measured gravity, and the computed gravity curve could not be distinguished from the measured gravity curve as presented on 


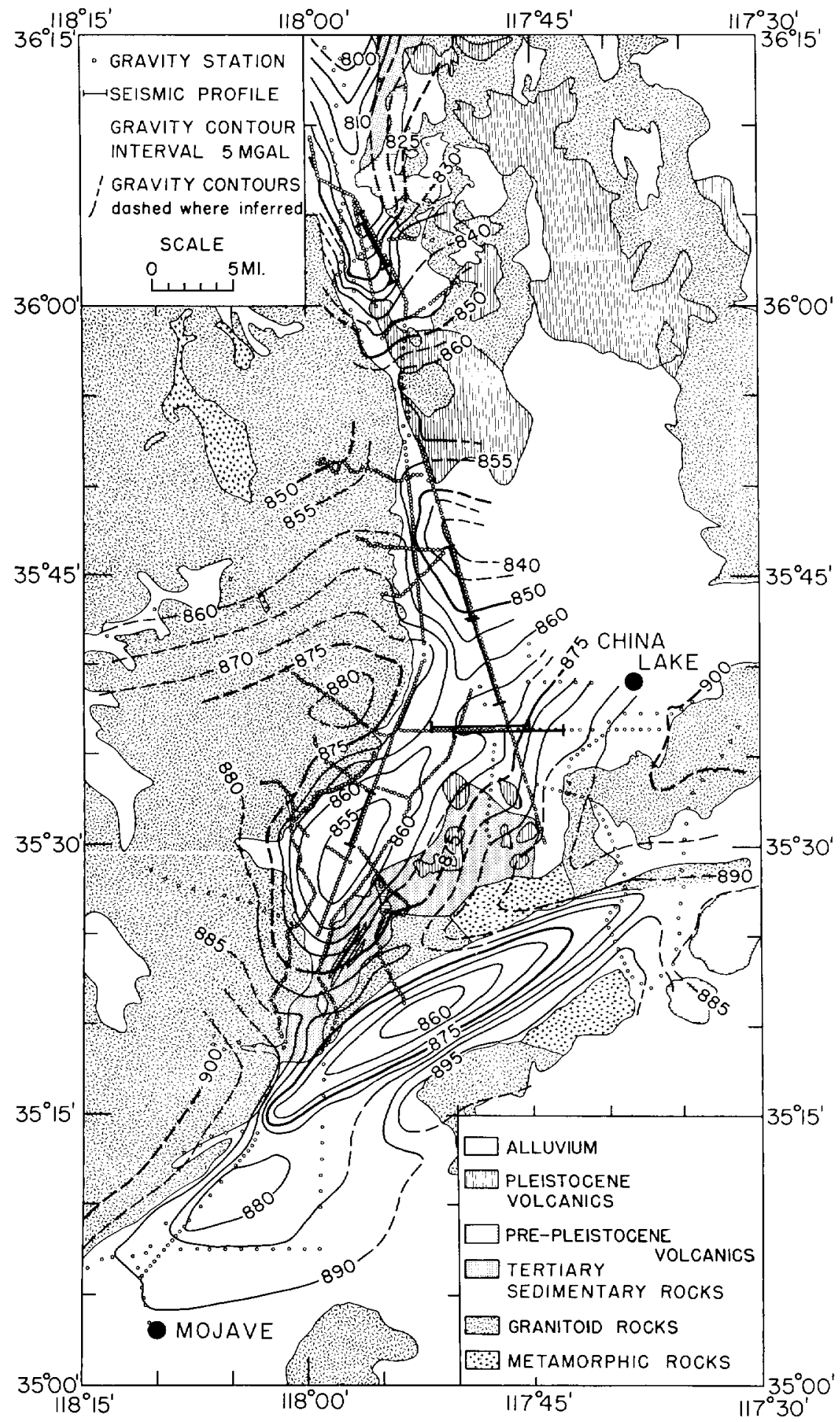

FIG. 8. Map of Bouguer gravity anomaly; $1,000 \mathrm{mgals}$ have been added to all gravity values. 
the cross-sections. The depths of the basin structures are plotted without vertical exaggeration.

\section{Gravity profiles in Rose Valley}

These profiles are presented in Figure 9, and show the Owens Valley structure continues into Rose Valley. Computed depths to basement reach 5,500 ft and would be greater if a lower density contrast were used in the interpretation.
A density contrast of $0.5 \mathrm{gm} / \mathrm{cc}$ was used, so these results are comparable to the interpretation of Kane and Pakiser (1961) on the northern extension of this structure.

Two attempts were made to get good basement arrivals on seismic-refraction profiles in this valley. A weak arrival with apparent velocity of 15,000 $\mathrm{ft} / \mathrm{sec}$ indicated a depth of about $2,000 \mathrm{ft}$, but this depth does not agree with the gravity interpretation. The most likely explanation for this disagree-

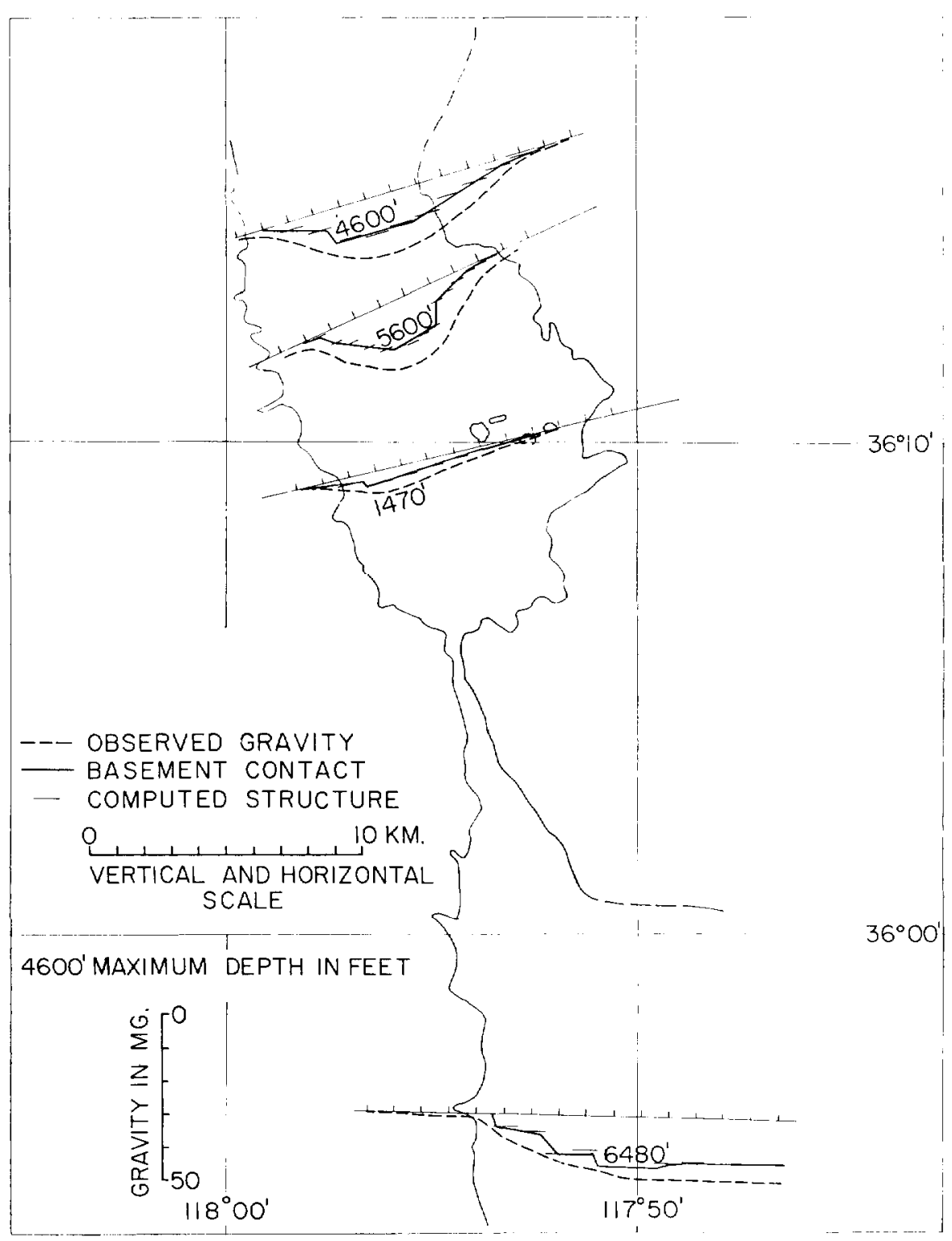

FIG. 9. Interpretation of gravity profiles in Rose Valley. 


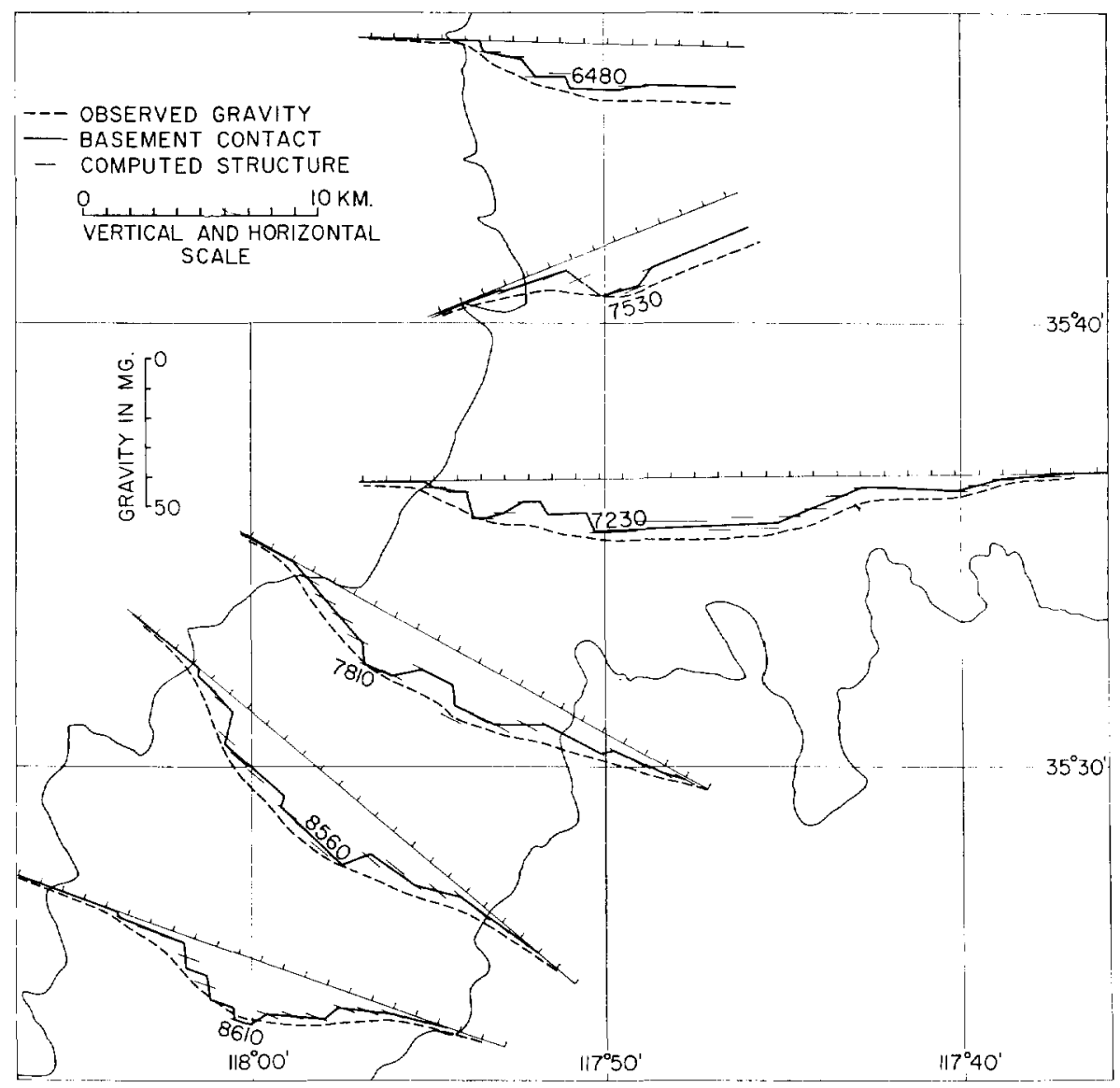

FIG. 10. Interpretation of gravity profiles in Indian Wells Valley.

ment is that the weak, high-velocity arrival comes from an interbedded volcanic layer.

The exact shape of the valley is difficult to determine because of the regional gradients. The depths of the basin are shallow in the vicinity of Haiwee Reservoir compared to the depths of the basin under Owens Lake, and south of Haiwee Reservoir the basin deepens into an oval-shaped depression.

\section{Gravity profiles in Indian Wells Valley}

These profiles are presented in Figure 10. The profiles were taken near actual gravity lines to reduce the extrapolation to a minimum. A density contrast of 0.35 was used on all profiles and gives a reasonably good agreement with the seismic data. Regional gradients were removed from individual profiles.

A number of faults are suggested by the profiles.
The main Sierra fault appears to be displaced into the basin about a mile from the contact between basin sediments and basement rock. A series of step faults gives a better fit to the gravity data than a single fault.

A comparison of two methods on the interpretation of Mabey's profile in Cantil Valley

The gravity anomaly over Cantil Valley is the sharpest anomaly in this region and is particularly important because of its relation to the Garlock fault. Mabey's (1960) profile across this valley was reinterpreted to provide a comparison between the automatic gravity interpretation program and the interpretative techniques used by Mabey.

Figure 6 shows basin configuration at three stages in the iterative computation used by the program. There is apparently no basin shape with 
a constant density contrast of $0.5 \mathrm{gm} / \mathrm{cc}$ that can produce the observed anomaly. Figure 11 shows similar results using density contrasts of 0.6 and $0.7 \mathrm{gm} / \mathrm{cc}$. We are forced to conclude that the observed anomaly cannot be explained without density variations within the basin deposits.

Figure 11 shows Mabey's interpretation compared to the automatic interpretation. There is good general agreement between these two interpretations; both show the existence of density contrasts within the basin, both show the basin floor dipping into the Garlock fault, and both indicate that the basin is bounded on either side by steep faults. Mabey's interpretation shows the Garlock as a vertical fault; a fault dipping about 60 degrees or two offset vertical faults would give a better fit to the automatic interpretation. The Cantil Valley fault shown on Mabey's profile would fit the automatic interpretation better if it was moved about two $\mathrm{km}$ toward the center of the basin. A reasonable interpretation of the observed gravity can be found without requiring a large throw on the El Paso fault as indicated by Mabey.

The power of machine methods in gravity interpretation is illustrated by this interpretation. Automatic computation allows the investigator to test many more solutions than would be possible in a reasonable period of time by manual computations. The program described in this paper is only a first attempt. Programs can be written that will take into account more variables. Seismic results, surface geology results, and variable density-depth relationships could all be inserted in the program in a relatively simple fashion.

\section{CONCLUSIONS}

Elongated basin structures follow the eastern front of the Sierra Nevada from the vicinity of Bishop to the southern termination of the range at the Garlock fault.

Kane and Pakiser's (1961) gravity data on southern Owens Valley and their survey covering northern Owens Valley (Pakiser and Kane, 1962) show that a narrow Cenozoic basin begins about 20 miles north of Bishop and continues southward to the Coso Mountains. The present study shows that this basin structure extends at shallower depths as far south as Little Lake. In the vicinity of Little Lake, granite crops out in the valley floor, but a few miles south of Little Lake the basin reforms and widens into a broad structure in Indian Wells Valley. The deep part of
Indian Wells Valley tends to parallel the front of the Sierra Nevada to the vicinity of Walker Pass where the basin structure narrows, turns with the front of the Sierra, and deepens in an oval-shaped basin between the Sierra Nevada and the El Paso Mountains.

With the exception of the interruption at Little Lake, basin structures follow the Sierra front for a distance of over 150 miles.

Kane and Pakiser's (1961) survey shows that the basin structure in southern Owens Valley is from 3 to 8 miles wide with depths between 3,000 and $8,000 \mathrm{ft}$. These results are supported by the seismic data reported in this paper.

The basin structure in southern Owens Valley narrows at the southern end of Owens Lake but continues through Rose Valley to Little Lake. Seismic profiles in Rose Valley did not reveal basement arrivals, but gravity profiles indicate depths of $5,500 \mathrm{ft}$.

Two faults intersecting nearly at right angles define the northwest corner of the basin structure under Indian Wells Valley. One of these faults paraliels the front of the Sierra; the other fault, which is indicated by the gravity data, is an eastwest-trending fault striking the Sierra front at about $35^{\circ} 50^{\prime}$ latitude.

A few miles southeast of the intersection of these faults, basement depths of $6,000 \mathrm{ft}$ are indicated by the seismic and gravity data. Basement depths of 5 to 6 thousand ft continue to about $35^{\circ} 35^{\prime}$ latitude, where the basin structure narrows and turns southwestward into an oval-shaped structure between the EI Paso Mountains and the Sierra Nevada. Depths here reach 7,500 ft.

The basin structure in Cantil Valley between the Rand Mountains and the El Paso Mountains and the basin structure between the El Paso Mountains and the Sierra Nevada are closely related features. Pliocene deposits uplifted in the Rand Mountains were probably deposited in a large basin including both of the basins mentioned above. Uplift of the El Paso Mountains during the Pleistocene divided the larger basin.

One of the most interesting observations from this survey is the persistent nature of the narrow basin structures along the front of the Sierra Nevada. It is difficult to account for this relationship between the basin structure and the Sierra Nevada unless both of these features result from the same tectonic process.

Since the floors of these nonmarine basins in 


\section{GRAVITY ANOMALY}

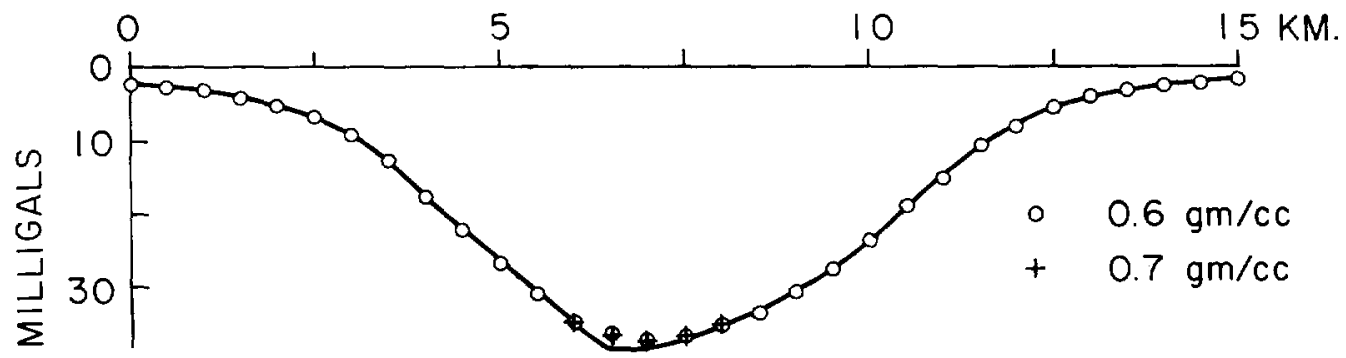

MABEY'S INTERPRETATION

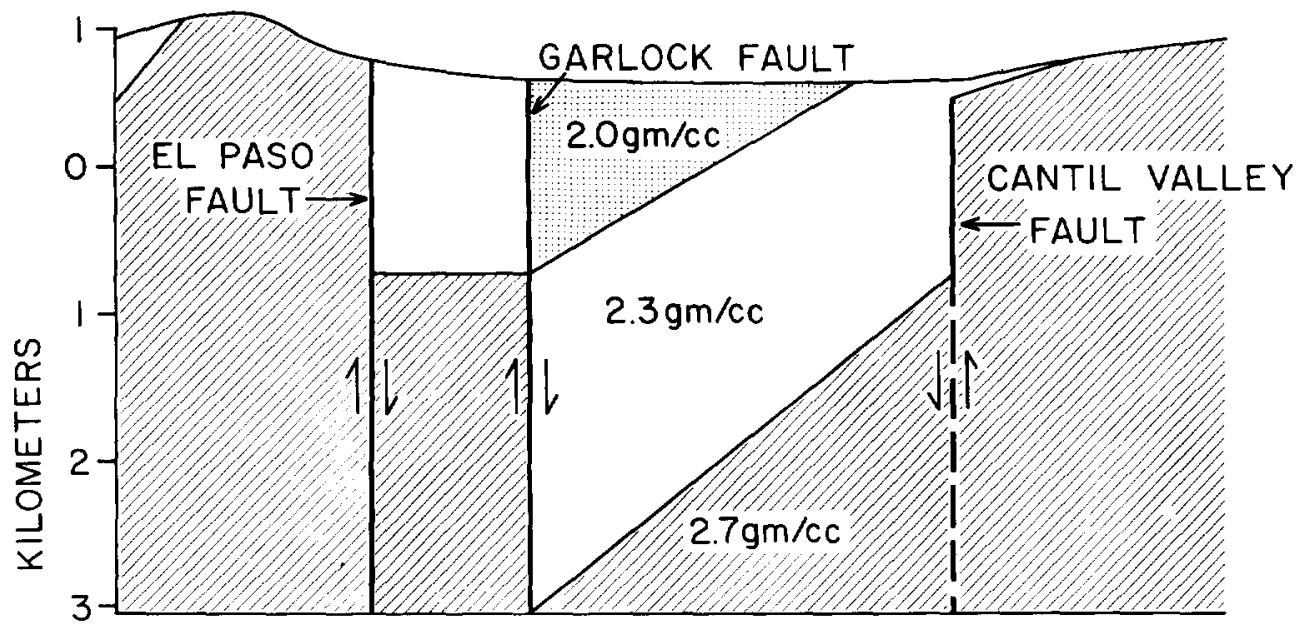

AUTOMATIC INTERPRETATION

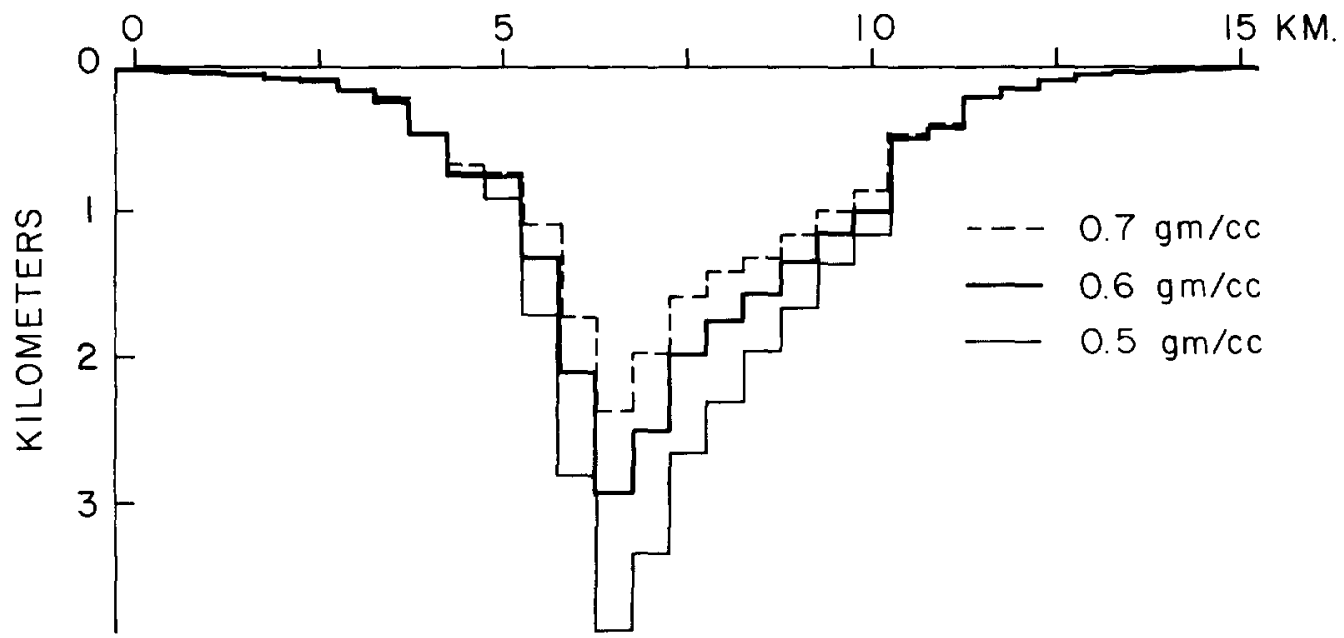

FIG. 11. Comparison of interpretation by digital computer with Mabey's interpretation in Cantil Valley. 
places lie thousands of feet below sea level, it is almost certainly established that these basins have been subsiding in an absolute sense. Other lines of evidence indicate the Sierra Nevada has attained the major part of its present elevation over the same period of time in which the basins have been sinking.

The contemporaneous rising of the mountains and sinking of the basins rules out tectonic hypotheses based on simple tension or simple compression. The individual mountain and basin structures are not isostatically compensated, but compensation appears to occur on a regional basis with no direct relationship to structural features observed at the surface. This suggests that isostasy has no direct role in the formation of these structures.

In addition to the anomalies caused by lowdensity Cenozoic sediments, anomalies which originate in the pre-Tertiary rocks of the crust are observed on the gravity map. There are regional anomalies presumably related to crustal thickening. Other anomalies of a more local character are related to density changes within the crust at shallow depths compared to the depth of the Mohorovičić discontinuity.

The magnitude of the Bouguer anomaly in the area of the survey is -100 to $-175 \mathrm{mgal}$. Near the coast, the Bouguer anomaly is near zero. In the western Mojave the anomaly is about -110 mgal. Along the western edge of the Sierra the anomaly parallels the trend of the Sierra and is about $-100 \mathrm{mgal}$. It is difficult to account for negative anomalies of this magnitude without requiring some crustal thickening. If $0.5 \mathrm{gm} / \mathrm{cc}$ is taken as crust-mantle density difference, a -175 mgal anomaly would require an increase of about $9 \mathrm{~km}$ in crustal thickness.

Examination of the regional anomalies in the area of the survey shows that they cannot be entirely explained by changes at the Mohorovičić discontinuity. The regional gradient alternates between areas of relatively small regional gradient to areas with regional gradients as high as three mgal per mile. These steep gravity gradients place severe limitations on the depths of anomalous masses.

We are, therefore, forced to the conclusion that density changes at the Mohorovičić discontinuity can contribute to the isostatic compensation only on a regional basis. A significant part of the observed compensation of the Sierra takes place at the intermediate discontinuity or higher in the crust. This conclusion is in agreement with the conclusion of Oliver, Pakiser, and Kane (1961) from their study of gravity in the central Sierra.

This area provides an excellent opportunity for the study of tectonic processes because the nature of movement severely restricts the number of hypotheses that might offer an explanation for the observed structures. The fact that the movement is continuing at present makes it possible to perform a number of important experiments. In particular, a detailed study of the nature and location of earthquakes with respect to these structures, and detailed knowledge of the variation of intermediate layers in the crust in this region, would provide important information about the tectonic process.

\section{ACKNOWLEDGMENTS}

Financial support for this study was provided by grants from the National Science Foundation (G-19778) and the American Petroleum Institute. The authors wish to express their appreciation to the Western Geophysical Company who furnished shot-hole drilling services at cost during the summer of 1961. Dr. Clarence Allen provided the fault map in Figure 2 and contributed many helpful suggestions during the course of the work and the preparation of the manuscript. L. C. Pakiser of the U. S. Geological Survey cooperated with us during the recording of profiles 1 and 2 and contributed the interpretation of these profiles. Messrs. Ralph Gilman, Laslo Lenches, Shelton Alexander, Dave Harkrider, Robert Kovach, Fred Tahse, and Robert Mason assisted with the seismic and gravity field work. Drs. Pierre SaintAmand and Roland E. von Huene provided assistance for the part of the work that was performed at the Naval Ordnance Test Station. The authors wish to express their appreciation to all of these people without whose assistance this project could not have been carried out.

\section{REFERENCES}

Bott, M. H. P., 1960, The use of rapid digital computing methods for direct gravity interpretation of sedimentary basins: Roy. Astron. Soc. Geophys. Jour., v. 3, p. $63-67$.

Dibblee, T. W., Jr., 1952, Geology of the Saltdale Quadrangle, California: Calif. Div. Mines Bull., 160.

Dix, C. H., 1952, Seismic prospecting for oil: New York, Harper and Brothers, $414 \mathrm{p}$.

Gutenberg, B., Wood, Harry O., and Buwalda, John P., 1932, Experiments testing seismographic methods 
for determining crustal structure: Bull. Seism. Soc. America, v. 22, p. 185-248.

Healy, J. H., 1961, Geophysical studies of basin structures along the eastern front of the Sierra Nevada, California: Ph.D. thesis, Calif. Inst. Tech.

Hobbs, W. H., 1910, The earthquake of 1872 in Owens Valley, California: Gerl. Beitr. Geophys., 10, p. 352-385.

Hopper, R. H., 1939, Geologic section from the Sierra Nevada to Death Valley: Ph.D. thesis, Calif. Inst. Tech.

Kane, M. F., and Pakiser, L. C., 1961, Geophysical study of the subsurface structure in southern Owens Valley, California: Geophysics, v. 26, p. 12-26.

Lawson, A. C., 1904, The geomorphology of the upper Kern Basin: Univ. Calif. Pub., Bull. Dept. Geol., 3, p. 291-376.

Mabey, D. R., 1956, Geophysical studies in southern California Basins: Geophysics, v. 21, p. 839-853.

- _ 1960, Gravity survey of the western Mojave Desert, California: U. S. Geol. Survey Prof. Paper No. 316-D.

Nettleton, L. L., 1942, Gravity and magnetic calculations: Geophysics, v. 7, p. 293-310.

Oliver, H. W., Pakiser, L. C., and Kane, M. F., 1961, Gravity anomalies in the Central Sierra Nevada, California: Jour. Geoph. Res., v. 66, p. 4265-4271.

Pakiser, L. C., and Kane, M. F., 1962, Geophysical study of Cenozoic geologic structures of Northern
Owens Valley, California: Geophysics, v. 27, p. 334-342.

- 1961, Gravity, volcanism and crustal deformation in Long Valley, California: U. S. Geol. Survey Prof. Paper 424-B, p. 250-253.

- Press, Frank, and Kane, M. F., 1961, Geophysical investigation of Mono Basin, California: Bull. Geol. Soc. Amer., v. 71, p. 415-448.

Press, Frank, 1960, Crustal structure in the CaliforniaNevada region: Jour. Geoph. Res., v. 65, p. 10391051.

Putnam, W. C., 1960, Faulting and Pleistocene glaciation in the East-Central Sierra Nevada of California, U.S.A.: Int. Geol. Cong. Rept. of Twenty-first Session.

Richter, C. F., 1958, Elementary seismology: San Francisco, W. H. Freeman and Company, 768 p.

-_ 1960, Earthquakes in Owens Valley, California, January-February, 1959: Bull. Seism. Soc. Amer., v. 50, p. 187-196.

Swick, C. H., 1942, Pendulum gravity measurements and isostatic reductions: U. S. Coast and Geodetic Survey Spec. Pub. 232.

Talwani, M. J., Worzel, L., and Landisman, M., 1959, Rapid gravity computations for two-dimensional bodies with applications to the Mendocino submarine fracture zone: Jour. Geoph. Res., v. 64, p. 49-59.

von Huene, Roland E., 1960, Ph.D. thesis, University of California, Los Angeles, Calif. 